\title{
Function of the uropygial gland in eiders (Somateria mollissima)
}

Anders Pape Møller ${ }^{1,2^{*}}$ (D) and Karsten Laursen ${ }^{3}$

\begin{abstract}
Background: The uropygial gland is an exocrine gland located above the tail of birds that produces a diverse range of biochemicals. It has been hypothesized to be involved in chemical protection, water-proofing and maintenance of plumage brightness. Although these not necessarily mutually exclusive functions have received some empirical support, there has been little empirical research on the function of water-proofing.

Methods: Here we analyzed data for 229 individual eiders (Somateria mollissima) collected by Danish hunters during 2016-2018.

Results: The Eider is a sea-duck that spends almost its entire life in sea water emphasizing water-proofing of the plumage. The size of the uropygial gland increased with body mass in males, but not in females, and it increased with age. The size of the uropygial gland decreased during winter. Eiders with small uropygial glands grew their feathers at a fast rate. Eiders with large wing areas had large uropygial glands.
\end{abstract}

Conclusions: These findings are consistent with large uropygial glands playing a role in water-proofing during molt and foraging, but also that uropygial glands may play a role in chemical defense.

Keywords: Anti-microbial substance, Eider, Somateria mollissima, Uropygial gland, Water-proofing

\section{Background}

The uropygial gland is a unique organ in birds situated above the rump. It produces a diversity of biochemical substances that are smeared with the beak on soft tissue and feathers. Given the amount of waxes produced, the amount of time allocated to preening may exceed $30 \%$ in wild birds (Møller 1991; Walther and Clayton 2005). The secretions are mainly a diverse array of volatile and non-volatile fatty acids that differ in composition with a strong phylogenetic signal (Jacob and Ziswiler 1982).

The function of the secretions by the uropygial gland has been hypothesized to vary from anti-microbial substances, waterproofing, drag reduction, and excretion of pollutants to intraspecific and interspecific communication (review in Elder 1954; Jacob and Ziswiler 1982; Salibián and Montalti 2009; Moreno-Rueda 2017). There is

\footnotetext{
*Correspondence: anders.moller@u-psud.fr

${ }^{1}$ Ministry of Education Key Laboratory for Biodiversity Science and Ecological Engineering, College of Life Sciences, Beijing Normal University, Beijing 100875, China

Full list of author information is available at the end of the article
}

little evidence consistent with any particular hypothesis, mainly because there are few studies that have investigated multiple hypotheses. Furthermore, there are few studies investigating any particular species during a number of years and sites. These studies have mainly focused on the Great Tit (Parus major) (Surmacki 2008; Galván and Sanz 2006, 2008; Galván 2011; Jacob et al. 2014) and House Sparrow (Passer domesticus) (Pap et al. 2010; Moreno-Rueda 2011; Czirják et al. 2013; Fülöp et al. 2016).

Another reason for the lack of consistency in research findings is the absence of studies investigating the fitness consequences of production of different amounts of secretions (Elder 1954; Salibián and Montalti 2009; Giraudeau et al. 2010a; Møller et al. 2010). There are only a small number of such studies published, while many others show no effects (e.g. A.P. Møller unpublished data on 2065 adult Barn Swallows Hirundo rustica).

Although the water-proofing hypothesis has been around since 1954 (Elder 1954), during the last 60 years there has been little additional evidence accumulated. 
Giraudeau et al. (2010a) showed for Mallards (Anas platyrhynchos) that placing a catheter over the gland impaired the condition of the plumage, although there was no information on whether this deterioration had any negative fitness consequences. Blocking access to uropygial glands did not reduce water retention by feathers (Giraudeau et al. 2010b). Giraudeau et al. (2013) showed that secretions from the uropygial gland of Mallards did not change the composition of feather degrading bacteria. In addition, experimental treatment did not affect the abundance of bacteria on eggs (Giraudeau et al. 2014). Bakken et al. (2006) showed for Mallard ducklings that secretions reduced water retention of feathers. However, the functions reported here are not necessarily mutually exclusive.

The eider (Somateria mollissima) is a capital breeder that builds up parts of its body reserves during winter for subsequent breeding (Meijer and Drent 1999; Jaatinen et al. 2016). When females arrive during spring to their breeding grounds they enter colonies and produce a clutch of 4-5 eggs with one egg laid daily and they are incubated for about 26 days with the females staying on the nest throughout the incubation period. Therefore, females must build up sufficient body reserves at the wintering grounds for breeding, supplemented with additional resources being ingested at the breeding grounds just before and during laying. Studies in the Wadden Sea show that individual eiders feeding on mussels have better body condition than those taking other types of prey, which makes it attractive for eiders to feed on mussel beds (Nehls and Ketzenberg 2002; Laursen and Frikke 2008; Laursen et al. 2009). During feeding eiders mostly dive 6-8 $\mathrm{m}$, but they are able to forage at $28 \mathrm{~m}$ (Petersen et al. 2006). Blue mussel (Mytilus edulis) can affect feeding conditions of eiders by increasing flesh content and by increasing the size of mussel stocks.

Since eiders in many respects live under extreme conditions at sea year-round, dive to great depth, are flightless during wing molt and accumulate great amounts of food before breeding, it is an obvious candidate for examining the function of the uropygial gland in relation to growth of feathers and size compared to other bird species. The objectives of this study were to assess (1) whether the size of uropygial glands affects daily growth increments; (2) whether molt takes place more rapidly among eiders with large uropygial glands; (3) whether the uropygial gland increases among eiders with larger wing areas, as expected because a large wing area requires more secretions from the uropygial gland; and (4) whether the size of the uropygial gland changes during the year as expected because of annual differences in use of secretions. To this end we used a sample of 229 eiders collected during 2016-2018. Eiders were sampled by hunters without prior knowledge of the purpose of the study, thereby ensuring that individuals were randomly sampled.

\section{Methods \\ Measurements of eiders}

We obtained samples of shot eiders in Denmark during 2016-2018 specifically collected under license from the Ministry of the Environment (SN-302-009, SNS-344600103, NST-3446-00018, NST-3465-00007) and the Government of Åland. The eiders were collected during winter in Denmark and during early spring at pre-breeding sites at Åland (February 10-May 11) in 2016-2018 (2016: $n=66 ; 2017: n=104,2018: n=59)$ by hunters at coastal localities across Denmark (34 sites) and Åland (6 sites).

Eiders were weighed to the nearest $0.1 \mathrm{~kg}$, sexed and aged using standard plumage characteristics (Cramp et al. 1982). For aging, females 1 - to 2 -years old were classified as sub-adults and $>2$ years as adults, 1 - to 4 -year old males were recorded as sub-adults and $>4$ years as adults.

APM and KL recorded morphological measurements of eiders in the laboratory. We removed the second primary and recorded its length with a ruler to the nearest $\mathrm{mm}$. We determined whether the tip of the second primary was broken.

We measured daily growth increments on the second primary by placing it on a piece of white paper under dim light (Grubb 2006). We marked the place where the first dark and light band started with a pin and then counted five such bands and then made a second marking. We measured the distance between these two marks with a digital caliper to the nearest $0.01 \mathrm{~mm}$ and then divided this measure by five to obtain an estimate of the average width of a single daily growth increment. Measuring five rather than a single growth bar minimizes measurement error. We subsequently made a second series of measurements of growth bar width to estimate repeatability of daily growth bar measurements (Falconer and Mackay 1996). Growth increment measurements were repeatable as shown by measurement of the same feathers twice $(R=0.68(\mathrm{SE}=0.05), F=66,379.57, d f=197$, $200, p<0.0001)$. We obtained an index of duration of the molting period by dividing the length of the second primary by the mean value of the two measurements of daily growth bar width.

We obtained estimates of aspect ratios for eiders as wingspan ${ }^{2} /$ wing area. Wingspan was measured with a ruler to the nearest $\mathrm{mm}$ (or to the nearest $\mathrm{cm}$ for larger species) according to Pennycuick's (2008) recommendations. Wing area was calculated by first accurately drawing the half-wing profile on a piece of paper with the 
leading edge of the wing being held at an angle of $90^{\circ}$ to the axis of the body and subsequently cutting the profile, weighing it on a precision balance and converting the weight to wing area using the weight of a reference surface of known area. Our estimates of wing area included the so-called root box, which is the area of the body between the wings (see Pennycuick 2008 for details).

\section{Statistical analyses}

We analysed the mass of the uropygial gland in relation to sex, body mass and their interaction. We developed Generalized Linear Models (GLM) for normally distributed data with an identity link function. The models were based on initial analyses of one response variable (mass of uropygial gland) in relation to sex, age and other relevant predictor variables. We report simple bivariate models and models that include a number of potentially confounding variables.

We estimated correlations among variables to avoid problems of multi-collinearity. However, variance inflation factors were all less than three, implying that there were no problems of collinearity (McClave and Sincich 2003). All analyses were made using JPM (SAS 2012).

\section{Results}

\section{Sex and age effects of eider on uropygial glands}

Males had 30\% larger uropygial mass than females [GLM with normally distributed data and identity link function: males: 5.34 g ( $\mathrm{SE}=0.08), n=116$; females: 4.06 (0.09), $n=113 ; \chi^{2}=93.09, d f=1, p<0.0001$; estimate $(\mathrm{SE})=0.64$ $(0.06)]$. The mass of the uropygial gland increased with body mass in males, but not in females in which uropygial mass was basically constant across the range of body masses [sex: $\chi^{2}=89.87, d f=1, p<0.0001$, estimate $(\mathrm{SE})=0.612(0.06)$; body mass; $\chi^{2}=6.67, d f=1, p=0.01$, estimate $(\mathrm{SE})=0.91(0.35)$; sex $\times$ body mass: $\chi^{2}=12.75$, $d f=1, p=0.0004$, estimate $(\mathrm{SE})=1.27(0.35)]$. Inspection of the interaction plot revealed that the size of the uropygial gland increased more strongly with body mass in males than in females. Age classes 2 and 3 years had smaller uropygial glands than age classes 4,5 and 6 years (Fig. 1; GLM with normally distributed data and identity link function: $\chi^{2}=12.23, d f=4,221, p=0.016$ ).

\section{Molt and mass of uropygial gland of eider}

The mass of the uropygial gland of eider decreased with the daily growth increments of feathers in a model that included wing area, age and date [Fig. 2; full model: $x^{2}=156.79, \quad d f=1, \quad p<0.0001 ;$ growth increment: $\chi^{2}=9.24, d f=1, p=0.0024$, estimate $(\mathrm{SE})=-0.44$ $(0.14)]$.

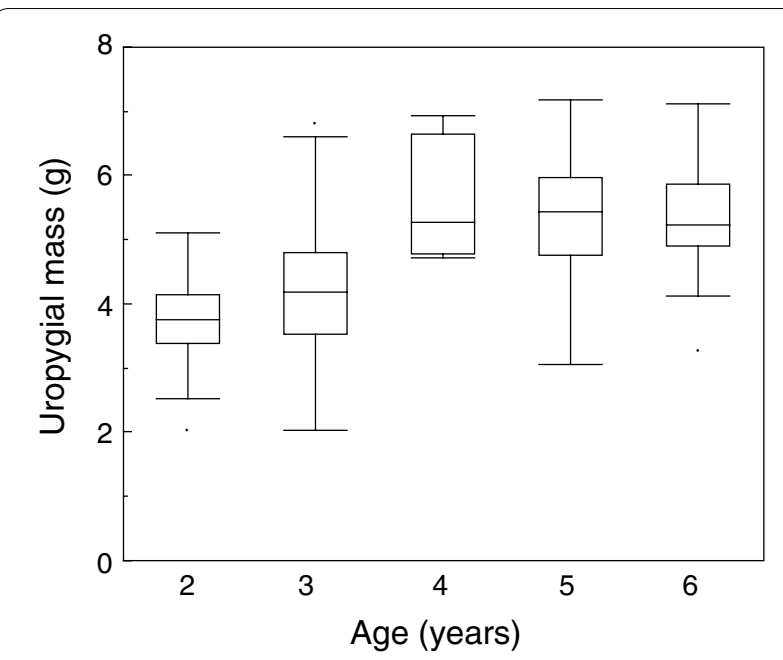

Fig. 1 Mass of the uropygial gland ( $\mathrm{g}$ ) in relation to age of eiders (years). The box plots show the medians, quartiles, 5- and 95-percentiles and extreme data points

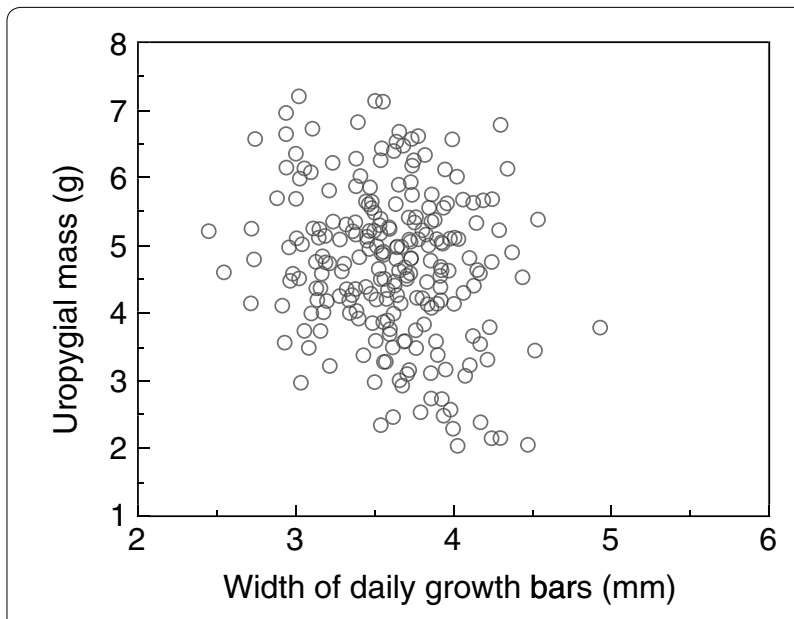

Fig. 2 Mass of uropygial glands in eiders ( $\mathrm{g}$ ) in relation to the mean daily growth increments of the second primary feather $(\mathrm{mm})$

The mass of the uropygial gland increased with the duration of the annual molt in a model that included wing area, age and date [Fig. 3; full model: $\chi^{2}=155.83$, $d f=1, \quad p<0.0001$; duration of molt: $\chi^{2}=8.28, d f=1$, $p=0.004$; estimate $(\mathrm{SE})=0.022(0.008)]$.

\section{Mass of the uropygial gland, flight and date of eider}

Wing area increased with mass of the uropygial gland of eider in an analysis that controlled for the effect of age (Fig. 4; full model: $\operatorname{LR} \chi^{2}=61.52, d f=1, p<0.0001$; wing area and uropygial gland: $\chi^{2}=8.39, d f=1, p=0.004$, estimate $(\mathrm{SE})=6.35(2.17)$; wing area and age: $\chi^{2}=28.14$, $d f=1, p<0.0001)$. In contrast, there was no significant 


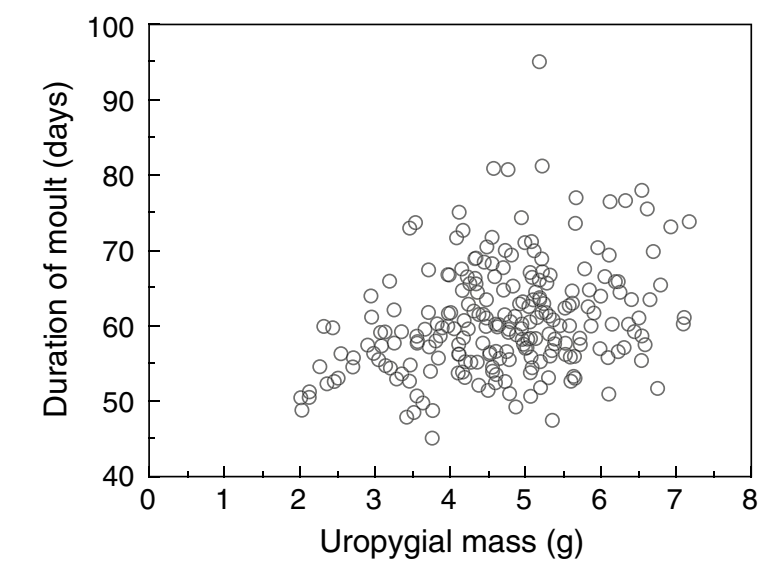

Fig. 3 Mass of uropygial glands in eiders $(\mathrm{g})$ in relation to duration of the annual molt of the second primary feather (days)

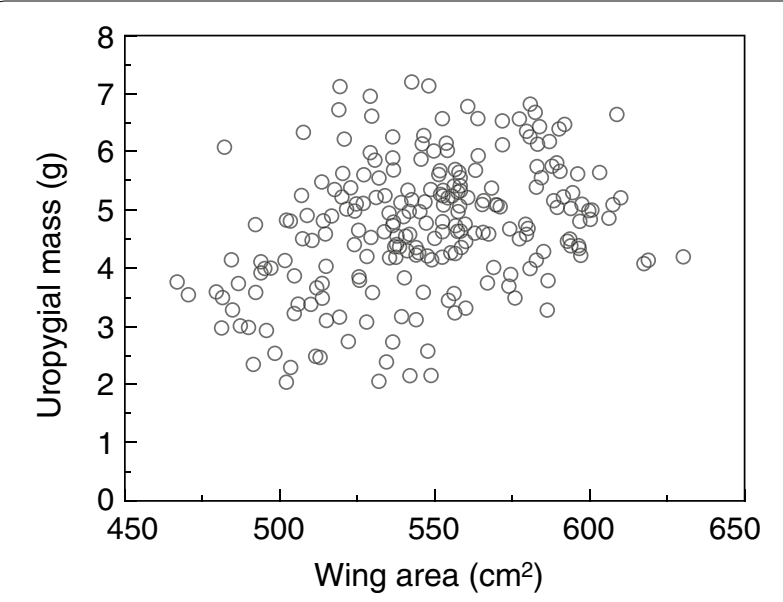

Fig. 4 Mass of uropygial glands in eiders $(\mathrm{g})$ in relation to area of the wings $\left(\mathrm{mm}^{2}\right)$

effect for aspect ratio of mass of the uropygial gland (LR $\left.\chi^{2}=0.22, d f=1, p=0.64\right)$.

The mass of uropygial glands fell during the year [Fig. 5; LR $\chi^{2}=10.97, d f=1, p=0.0009$, estimate $(\mathrm{SE})=-0.011$ (0.003)]. An analysis that controlled statistically for the effect of age and sex showed an even stronger partial effect of date [full model: LR $\chi^{2}=144.82, d f=1$, $p<0.0001$; age: LR $\chi^{2}=16.26, d f=1, p=0.0027$; sex: LR $\chi^{2}=0.31, d f=1, p=0.58$, estimate $\left.-0.20(\mathrm{SE}=0.36)\right]$.

\section{Discussion}

The exocrine uropygial gland has been hypothesized to water-proof the plumage of birds, especially that of aquatic birds, although other functions have also been proposed. We made extensive analyses of phenotypic variation in size of the uropygial gland. The mass of the uropygial gland increased with age, but decreased with

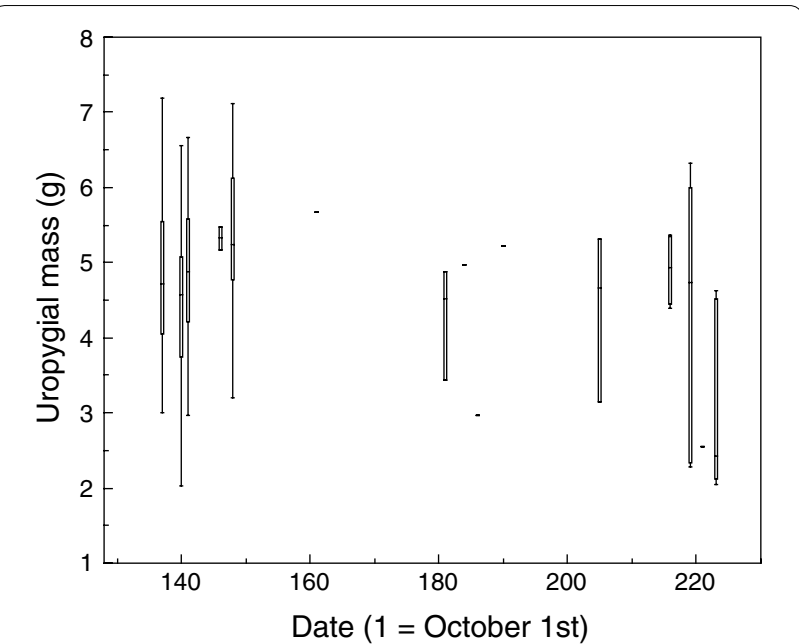

Fig. 5 Mass of uropygial glands in eiders ( $g$ ) in relation to the number of days since October 1st (days). The box plots show medians, quartiles, 5- and 95-percentiles and extreme data points

the width of the daily growth increments during molt, the duration of the annual molt and time during the year.

Sex roles differ in eiders with females producing, laying and incubating eggs with no food consumed during incubation, while males compete for access to females during an extended mating period in spring (Cramp 1977; Waltho and Coulson 2015). Since males spend more time in water than females, we should expect males to have larger uropygial glands than females if the function of uropygial secretions is water-proofing. In fact, males had $30 \%$ larger glands than females, as we would expect from the larger amount of time that males spend in water compared to females. The size of uropygial glands differed among age classes, with glands being significantly smaller among the two youngest age classes compared to older individuals. Younger birds spend more time in water than older individuals, and thus we should expect larger glands in older eiders if the function of secretions was water-proofing.

Eiders molt during a short period by losing their flight feathers to allow for rapid replacement (Salomonsen 1968; Waltho and Coulson 2015). Here we found evidence consistent with a trade-off between molt and size of uropygial glands. While there is a factor two difference in daily growth increments among eiders (Fig. 4), previous research has indicated that rapid feather growth occurs at the cost of production of poor quality feathers (Vágási et al. 2016; Møller and Nielsen 2018). We also found that the total duration of molt was positively related to the mass of the uropygial gland (Fig. 3). This implies that more resources are allocated to uropygial 
secretions when eiders spend more time molting. Larger uropygial glands imply that more secretions are allocated to water-proofing of feathers, but also that feathers would be less affected by draft when eiders dive.

Uropygial gland size and wing area could be adaptations to migration, or it could be adaptations to predator avoidance when eiders lose flight ability during molt. Large wing area for a given body mass implies lower costs of flight during migration (Vágási et al. 2016). Larger uropygial glands imply reduced drag of the plumage during flight (Thomas et al. 2010). Because males migrate earlier to the breeding grounds than females and older eiders migrate earlier than juveniles, we should expect selection for larger uropygial glands. This is consistent with larger uropygial glands in males than in females.

The size of uropygial glands decreased with the number of days since October 1st. This decrease in mass of uropygial glands could either arise from phenotypic plasticity, or it could be due to selective disappearance of individuals later during the season prior to breeding.

Since this paper is descriptive and correlational, it has its limitations. Still the large sample size is a unique feature that allows a number of tests that have been missing from the scientific literature dealing with the subject. There are a number of perspectives derived from this study. It would be desirable to analyze the microbial community of eiders and relate it to the size of uropygial glands. Such analyses would also allow investigation of the link between the microbial community of the down in nests and on adult eiders, respectively, and hatching success, allowing for assessment of whether the size of uropygial glands has fitness consequences.

In conclusion, phenotypic variation in the size of the uropygial gland of eiders revealed evidence consistent with a function of water-proofing, but also antimicrobial defense.

\section{Acknowledgements}

We thank the hunters from Denmark and Åland for collecting eiders.

\section{Authors' contributions}

APM and $\mathrm{KL}$ conceived and designed the study. APM and $\mathrm{KL}$ collected the data. APM analyzed the data. APM and KL wrote the manuscript. Both authors read and approved the final manuscript.

\section{Funding}

We obtained funding from the 15 June Foundation, Denmark.

\section{Competing interests}

The authors declare that they have no competing interests.

\section{Ethics approvals and consent to participate}

The study was approved by Ministry of the Environment (SN-302-009, SNS3446-00103, NST-3446-00018, NST-3465-00007) and The Government of Åland.

\section{Author details}

${ }^{1}$ Ministry of Education Key Laboratory for Biodiversity Science and Ecological Engineering, College of Life Sciences, Beijing Normal University, Beijing 100875, China. ${ }^{2}$ Ecologie Systématique Evolution, Université Paris-Sud, CNRS, AgroParisTech, Université Paris-Saclay, 91405 Orsay Cedex, France.

${ }^{3}$ Department of Bioscience, Aarhus University, Grenåvej 14, Kalø, 8410 Rønde, Denmark.

Received: 22 October 2018 Accepted: 11 June 2019

Published online: 05 July 2019

\section{References}

Bakken GS, Banta MR, Higginbotham CM, Lynott AJ. It's just ducky to be clean: The water repellency and water penetration resistance of swimming mallard Anas platyrhynchos ducklings. J Avian Biol. 2006;37:561-71.

Cramp S (ed). Handbook of the birds of the Western Palaearctic. Vol 1. Oxford: Oxford University Press; 1977.

Cramp S, Simmons KEL, Perrins CM, editors. Handbook of the birds of Europe, the Middle East and North Africa, vol 1-9. Oxford: Oxford University Press; 1982-1994

Elder WH. The oil gland of birds. Wilson Bull. 1954;66:6-31.

Falconer S, Mackay TFC. Introduction to quantitative genetics. 4th ed. New York: Longman; 1996.

Fülöp A, Czirják GA, Pap PL, Vágási Cl. Feather-degrading bacteria, uropygial gland size and feather quality in House Sparrows Passer domesticus. Ibis. 2016;158:362-70.

Galván I. No effect of uropygial gland secretion on hatching success in great tits Parus major. Rev Ecol. 2011;66:93-7.

Galván I, Sanz JJ. Feather mite abundance increases with uropygial gland size and plumage yellowness in Great Tits Parus major. Ibis. 2006;148:687-97.

Galván I, Sanz JJ. The cheek plumage patch is an amplifier of dominance in Great Tits. Biol Lett. 2008;4:12-5.

Giraudeau M, Czirják GA, Duval C, Bretagnolle V, Eraud C, McGraw KJ, Heeb P. Effect of restricted preen-gland access on maternal self-maintenance and reproductive investment in mallards. PLOS ONE. 2010a;5:e13555.

Giraudeau M, Duval C, Guillon N, Bretagnolle V, Gutierrez C, Heeb P. Effects of access to preen gland secretions on mallard plumage. Naturwissenschaften. 2010b;97:577-81.

Giraudeau M, Czirják GA, Duval C, Bretagnolle V, Gutierrez J, Guillon N, Heeb P. Effect of preen oil on plumage bacteria: an experimental test with the mallard. Behav Proc. 2013;92:1-5.

Giraudeau M, Czirják GA, Duval C, Bretagnolle V, Gutierrez C, Heeb P. An experimental test in Mallards (Anas platyrhynchos) of the effect of incubation and maternal preen oil on eggshell microbial load. J Ornithol. 2014;155:671-7.

Grubb TC Jr. Ptilochronology. New York: Oxford University Press; 2006.

Jaatinen K, Öst M, Hobson KA. State-dependent capital and income breeding: a novel approach to evaluating individual strategies with stable isotopes. Front Zool. 2016:13:24.

Jacob S, Immer A, Leclaire S, Parthuisot N, Ducamp C, Espinasse G, Heeb P. Uropygial gland size and composition varies according to experimentally modified microbiome in Great tits. BMC Evol Biol. 2014;14:134.

Jacob J, Ziswiler W. The uropygial gland. In: Farner DS, King JR, Parkes KC, editors. Avian biology, vol. VII. New York: Academic Press; 1982. p. 359-62.

Laursen K, Frikke J. Hunting from motorboats displaces Wadden Sea Eiders Somateria mollissima from their favoured feeding distribution. Wildl Biol. 2008;14:423-33.

Laursen K, Asferg K, Frikke J, Sunde P. Mussel fishery affects diet and reduces body condition of Eiders Somateria mollissima in the Wadden Sea. J Sea Res. 2009:62:22-30.

McClave JT, Sincich T. Statistics. 9th ed. Englewood Cliffs: Prentice-Hall; 2003.

Meijer T, Drent R. Re-examination of the capital and income dichotomy in breeding birds. Ibis. 1999;141:399-414.

Moreno-Rueda G. House sparrows Passer domesticus with larger uropygial glands show reduced feather wear. Ibis. 2011;153:195-8.

Moreno-Rueda G. Preen oil and bird fitness: a critical review of the evidence. Biol Rev. 2017;92:2131-43. 
Møller AP. Preening activity of swallows Hirundo rustica, in relation to experimentally manipulated loads of haematophagous mites. Anim Behav. 1991;42:251-60.

Møller AP, Erritzøe J, Nielsen JT. Predators and microorganisms of prey: Goshawks prefer prey with small uropygial glands. Funct Ecol. 2010;24:608-13.

Møller AP, Nielsen JT. The trade-off between rapid feather growth and impaired feather quality increases risk of predation. J Ornithol. 2018:159:165-71.

Nehls G, Ketzenberg C. Do common eiders Somateria mollissima exhaust their food resources? A study on natural mussel Mytilus edulis beds in the Wadden Sea. Dan Rev Game Biol. 2003;16:47-61.

Pap PL, Vágási Cl, Osváth G, Murecan C, Barta Z. Seasonality in the uropygial gland size and feather mite abundance in house sparrows Passer domestiCus: Natural covariation and an experiment. J Avian Biol. 2010;41:653-61. Pennycuick CJ. Modelling the flying bird. London: Academic Press; 2008.

Petersen IK, Pihl S, Hounisen JP, Holm TE, Therkildsen O, Christensen TK, Landsdækkende optælling af vandfugle januar-februar 2004. Faglig rapport fra
DMU, No. 606. Miljøministeriet, Denmark: Danmarks Miljøundersøgelser; 2006

Salibián A, Montalti D. Physiological and biochemical aspects of the avian uropygial gland. Braz J Biol. 2009;69:437-46.

Salomonsen F. The moult migration. Wildfowl. 1968;19:5-24.

SAS. JMP version 10.2. Cary, NC: SAS Institute, Inc; 2012.

Surmacki A. Preen waxes do not protect carotenoid plumage from bleaching by sunlight. Ibis. 2008;150:335-41.

Thomas RH, Price ER, Seewagen CL, Mackenzie SA, Bernards MA, Guglielmo CG. Use of TLC-FID and GC-MS/FID to examine the effects of migratory state, diet and captivity on preen wax composition in white-throated sparrows Zonotrichia albicollis. Ibis. 2010;152:782-92.

Vágási C, Pap PL, Vincze O, Osváth O, Erritzøe J, Møller AP. Morphological adaptations to migration in birds. Evol Biol. 2016;43:48-59.

Walther BA, Clayton DH. Elaborate ornaments are costly to maintain: evidence for high maintenance handicaps. Behav Ecol. 2005;16:89-95.

Waltho C, Coulson J. The common eider. London: T. \& A.D. Poyser; 2015.
Ready to submit your research? Choose BMC and benefit from:

- fast, convenient online submission

- thorough peer review by experienced researchers in your field

- rapid publication on acceptance

- support for research data, including large and complex data types

- gold Open Access which fosters wider collaboration and increased citations

- maximum visibility for your research: over 100M website views per year

At BMC, research is always in progress.

Learn more biomedcentral.com/submissions 